\title{
Новий метод рішення системи двогрупових дифузійних рівнянь для програмного забезпечення CBPK BBEP-1000
}

- Аксьонов Артем В'ячеславович

ПрАТ «СНВО «Імпульс», м. Сєвєродонецьк, Луганська обл., Україна

ORCID: https://orcid.org/0000-0002-3480-1696

- Трофименко Олександр Русланович

ПрАТ «СНВО «Імпульс», м. Сєвєродонецьк, Луганська обл., Україна

ORCID: https://orcid.org/0000-0002-7704-0911

- Будік Дмитро Володимирович

ПрАТ «СНВО «Імпульс», м. Сєвєродонецьк, Луганська обл., Україна

ORCID: https://orcid.org/0000-0002-3396-5832

- Носовський Анатолій Володимирович, акад. НАНУ, д-р техн. наук, проф. Інститут проблем безпеки АEC Національної академії наук України, м. Київ, Україна ORCID: https://orcid.org/0000-0002-2594-3780

- Гулік Володимир Іванович, канд. техн. наук

ПрАТ «СНВО «Імпульс», м. Сєвєродонецьк, Луганська обл., Україна

ORCID: https://orcid.org/0000-0002-3790-8392

Точна та оперативна інформація про експлуатаційні характеристики ядерного реактора, джерелом якої $\epsilon$ система внутрішньореакторного контролю, дає змогу оцінити рівень безпеки у процесі експлуатації енергоблоків АЕС. На цей час в Україні завершується розробка власного математичного забезпечення для системи внутрішньореакторного контролю ВBEP-1000, що $\epsilon$ однією із важливих умов реалізації програми диверсифікації ядерного палива. Науковий колектив ПрАТ «СНВО «Імпульс» розробив математичне забезпечення національного розрахункового комплексу на основі гібридного методу рішення системи двогрупових дифузійних рівнянь, що об'єднує в собі метод кінцевих різниць та нодальний метод. У статті наведено методологію рішення системи двогрупових дифузійних рівнянь гібридним методом для гексагональної геометрії. Наведено порівняння розрахунку, виконаного розробленим кодом на основі гібридного методу, з даними, зазначеними в бенчмарку AER-FCM101. Результати порівняння з бенчмарком свідчать про високу точність розробленого програмного забезпечення для розрахунку стаціонарного стану активної зони. Показано, що можна досягти відхилення від результатів бенчмарка приблизно 2-3 рст для ефективного коефіцієнта розмноження. Найкраще узгодження з бенчмарком по енерговиділенню (для $\mathrm{K}_{v}$ максимальне відхилення - 1,52 \%, середньо-квадратичне відхилення - 0,531 \%) досягається за 54 нодами на одну тепловидільну збірку в плані та за 24 однаковими за висотою шарами в аксіальному напрямку. Гібридний метод, для тієї самої розрахункової сітки, дає вищу точність ніж метод кінцевих різниць, особливо в областях з високою неоднорідністю розподілу нейтронів.

Ключові слова: бенчмарк AER-FCM101, гібридний метод, програмне забезпечення, розрахунок ядерного реактора, система внутрішньореакторного контролю.

( ) Аксьонов А. В., Трофименко О. Р., Будік Д. В., Носовський А. В., Гулік В. І., 2021 


\section{Вступ}

Безпечна експлуатація ядерних енергетичних реакторів $\epsilon$ найважливішим елементом подальшого розвитку атомної енергетики. Для забезпечення безпечної експлуатації енергоблоків АЕC необхідно мати точну та оперативну інформацію про експлуатаційні характеристики ядерної установки. Основним джерелом такої інформації на ядерних реакторах ВВЕР $€$ система внутрішньореакторного контролю (CВPK) [1]. Головна задача СВРК - оперативний контроль розподілу енерговиділення та його функціоналів у процесі експлуатації ядерного реактора [2].

Станом на сьогодні, у світі було розроблено та експлуатуються СВРК різних виробників: BEACON (Westinghouse), 3D-Monicore (General Electric Corporation), COLSS (Combustion Engineering), PowerPlex (Areva), GARDEL (Studsvik), SCORPIO (NRI Řež, CZEC Republic), КРУИЗ та ВОЯЖ (СНІІП-АТОМ, Росія), Хортиця (РНЦ «Курчатовський інститут», Росія) [3]. Усі ці СВРК експлуатуються в різних країнах та на різних типах ядерних реакторів. В Україні на блоках ВВЕР-1000 в основному експлуатуються СВРК, які були розроблені в період 1999 - 2013 рр. ПрАТ «СНВО «Імпульс» у співпраці 3 російськими виробниками (СНІІП-АТОМ та РНЦ «Курчатовський інститут»). У цих системах розрахункові функції виконують програмні комплекси (ПК) КРУИЗ/ВОЯЖ та Хортиця [2]. На декількох блоках як розрахунковий комплекс використовується також ПК BEACON компанії Westinghouse [4].

Диверсифікація постачальників ядерного палива дала можливість експлуатації нових типів ядерного палива виробництва компанії Westinghouse (TB3-W та TB3-WR) на енергоблоках AEC України [5]. Наявність аксіального профілювання палива (так звані низькозбагачені бланкети) виробництва компанії Westinghouse не дає можливості використовувати наявні ПК російського виробництва без суттєвих модифікацій [6].

У кінці 2016 року на засіданні науково-технічної ради ДП «НАЕК «Енергоатом» було ухвалене рішення про розробку і впровадження національного розрахункового комплексу (НPK) [7], з метою створення повністю вітчизняної СBPK на АEC України. Згодом, для реалізації цієї задачі, було підготовлене технічне завдання ИТКЯ.421412.114Т3 [8] на розроблення НРК визначення нейтроннофізичних і теплогідравлічних параметрів реакторної установки та створення модернізованого комплексу уніфікованого програмного забезпечення CBPK енергоблоків BВEP-1000 АЕС України. На цей час завершується розробка НРК та програмного забезпечення вітчизняної СBPK.

Метою статті $\epsilon$ продемонструвати методологію рішення двогрупового рівняння дифузії нейтронів в активній зоні реактора гібридним методом, що використовується в НРК, який входить до складу вітчизняної СВРК як підсистема фізичних розрахунків (ПФР). Розроблений у ПрАТ «СНВО «Імпульс» HPK отримав назву «ImCore». Також стаття демонструє порівняння розрахунку, виконаного НРК на основі гібридного методу, з даними, наведеними в бенчмарку AER-FCM101 [9].

\section{Розрахунок ядерного реактора детерміністичними методами}

Для розрахунку переносу нейтронів у ядерному реакторі потрібно знати розподіл ядерних реакцій за заданих граничних умов. Усі детерміністичні методи розрахунку ядерних реакторів виводяться 3 теорії переносу. Загальний принцип теорії переносу не складний, оскільки він базується на простих законах збереження та на декількох математичних визначеннях [10], [11]. Багато в чому теорія переносу для нейтронів подібна до переносу молекул у рідині або дрейфу іонів та електронів у плазмі.

Утім теорія переносу нейтронів має свої суттєві риси. Однією з характерних особливостей розрахунку переносу нейтронів $\epsilon$ складна енергетична залежність поперечних перерізів взаємодії нейтронів з ядрами в середовищі. Ще однією суттєвою властивістю переносу нейтронів $\epsilon$ те, що нейтрони не відчувають кулонівських потенціалів оточуючих атомів. Сили, що діють під час зіткнень, мають дуже обмежений радіус дії, а траєкторію нейтрона між розсіюваннями можна описати відрізками прямих [12]. Основними припущеннями під час розрахунку переносу нейтронів $\epsilon$ те, що нейтрони можна розглядати як точкові частинки, що рухаються прямими лініями між точками розсіювання, і що всі нейтрон-нейтронні взаємодії можна ігнорувати. Для подальшого спрощення розрахунку часто робляться додаткові припущення.

Усі детерміністичні методи розрахунку густини потоку нейтронів основані на чисельному розрахунку рівняння переносу нейтронів. Основна проблема розв'язку полягає не в математичному формулюванні рівнянь, а в складній кутовій та енергетичній залежності перерізів та джерел нейтронів. Точний розв'язок кутової залежності неможливий, і для знаходження рішення потрібно застосовувати наближені методи та додаткові припущення. На сьогодні, існує чотири основні категорії детерміністичних методів вирішення рівняння переносу нейтронів:

1) метод характеристик;

2) метод ймовірностей перших зіткнень;

3) метод дискретних ординат (або Sn-метод);

4) метод сферичних гармонік (або $\mathrm{Pn}$-метод).

Дифузійне наближення має свої обмеження, але воно широко та успішно використовується в різних розрахунках водо-водяних ядерних реакторів. Теорія дифузії нейтронів $\epsilon$ окремим випадком методу сферичних гармонік першого порядку (Р1). 
Рішення системи двогрупових дифузійних рівняньіз заданимиграничними умовами реалізується за допомогою сучасних нодальних методів [13]-[15] та методів кінцевих різниць [16] (або методів кінцевих елементів [17]). Під час використання методу кінцевих різниць (МКР) на сітці з великим кроком можна дуже швидко проводити розрахунок всієї активної зони, втім точність МКР може бути невисокою. Нодальні методи зазвичай вимагають більше комп'ютерного ресурсу для розрахунку стану активної зони, але дозволяють рахувати на сітках з більшим кроком ніж МКР без втрати точності розрахунку. Зважаючи на вимоги технічного завдання на розробку HРК [8] як до точності, так і до швидкості розрахунку, авторами запропоновано використати розроблений гібридний метод вирішення системи двогрупових дифузійних рівнянь [18]. Цей метод застосовує МКР у радіальній площині та нодальний метод - в аксіальному напрямку, що дозволяє досягти оптимуму між точністю і швидкістю розрахунку для задач моніторингу в СВРК.

\section{Гібридний метод для гексагональної} геометрії

Для того, щоб визначити ефективний коефіці$\epsilon$ т розмноження нейтронів і стаціонарний розподіл енерговиділення в активній зоні, розв'язуються багатогрупові рівняння переносу нейтронів у дифузійному наближенні, які можна записати у вигляді (див., наприклад, [19]):

$$
\begin{gathered}
\nabla \vec{J}_{g}+\Sigma_{r g} \phi_{g}=Q_{g}, \\
\vec{J}_{g}=-D_{g} \nabla \phi_{g}, \\
Q_{g}=\frac{\chi_{g}}{\lambda} \sum_{g^{\prime}=1}^{G} \nu \Sigma_{f g^{\prime}} \phi_{g^{\prime}}+\sum_{\substack{g^{\prime}=1 \\
g^{\prime} \neq g}}^{G} \Sigma_{s g g^{\prime}} \phi_{g^{\prime}} \cdot
\end{gathered}
$$

Тут $G$ відповідає кількості груп, усі інші позначення стандартні, які використовуються в літературі. Для практичних розрахунків застосовувалося двогрупове наближення. Тут рівняння (1) - рівняння балансу нейтронів, (2) - закон Фіка, а формула (3) визначає джерела нейтронів для правої

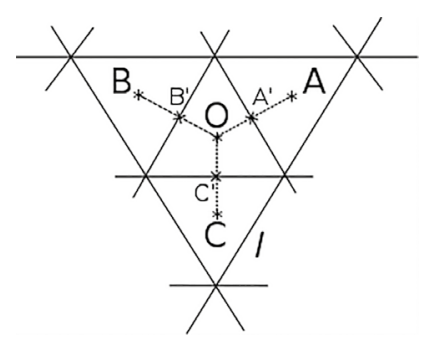

Рисунок 1 - Радіальне розбиття на ноди частини рівняння (1). Щоб отримати коректну постановку задачі, до (1) - (3) додають граничні умови та умову нормування у вигляді:

$$
\sum_{g=1}^{G} \int \Sigma_{f g} \phi_{g} d V=P .
$$

Інтегрування в (4) відбувається по всьому об'єму активної зони. Умова (4) використовується для нормування густини потоку нейтронів відповідно до рівня потужності реактора $\mathrm{P}$.

Рівняння (1) - (4) чисельно розв'язуються ітераційним методом з розподілом ітерацій на зовнішні та внутрішні. Внутрішні ітерації в кожній енергетичній групі виконуються роздільно з використанням у (1) сталого джерела нейтронів поділу. Також передбачається, що розбиття на ноди (підобласті, в цьому випадку - трикутні призми) вже виконано і проведена гомогенізація складу кожної ноди. Зауважимо, що в роботах [18], [20] гібридний метод застосовувався для нод у вигляді прямокутних призм.

Використана в побудові розрахункової схеми ідея гібридного методу викладена у роботах [18], [20]. Його суть полягає в такому - внутрішні ітерації розбиваються на два кроки: перший визначає середнє значення густини потоку в нодах, що знаходяться в одній площині, методом кінцевих різниць (finite difference method), а другий визначає парціальні струми через межі суміжних призм, що знаходяться на одній осі, нодальним методом (nodal expansion method). На першому кроці струми між призмами, що знаходяться в двох сусідніх аксіальних площинах, вважаються незмінними, на другому - середні поперечні витоки.

Опишемо розбиття активної зони на ноди. Область, у якій вирішуються рівняння дифузії (реактор, активна зона, тепловидільна збірка (ТВ3) тощо) замінюється областю, розбитою на прямі трикутні призми однорідного складу. Ескізи взаємного розташування призм наведені на Рисунку 1 і Рисунку 2.

Усі призми мають однакову геометрію (конгруентні): в основах лежать рівносторонні трикутники, а бічні грані прямокутні.

Точки на Рисунках 1 і 2, відмічені латинськими літерами O, A, B, C, U, L, знаходяться в геометричних центрах відповідних призм. Для стислості призми також будуть називатися цими літерами.

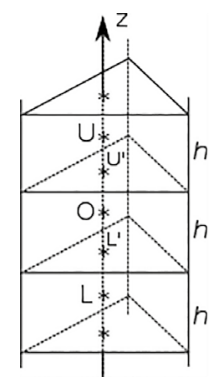

Рисунок 2 - Аксіальне розбиття на ноди 
Наприклад, призма О - це призма з центром у точці О. Призма О має спільні грані з п'ятьма іншими призмами: бічні - 3 призмами А, В і С, основи - 3 призмами U i L. Центри спільних граней відмічені літерами A', B', C', U' та L'. Як і у випадку з призмами, назви граней позначаються тими ж літерами, що й точки в їх центрах. Наприклад, грань А' - це грань із центром у точці A'.

Необхідні розрахункові рівняння нижче будуть отримані в загальному випадку для призми О, яка не має граней, що лежать на межі активної зони. Призми, які мають такі грані, розглядаються окремо з урахуванням відповідних граничних умов.

Оскільки вигляд рівнянь (1) - (2) не залежить від номера групи, то всюди нижче індекси групи опускаються. Рівняння балансу (1) проінтегруємо за об'ємом ноди, усереднюючи величини, що входять в рівняння:

$$
\bar{L}_{O}+\bar{L}_{U^{\prime}}+\bar{L}_{L^{\prime}}+\Sigma_{O} \bar{\phi}_{O}=\bar{Q}_{O}
$$

Тут середній поперечний витік у радіальній площині визначено формулою:

$$
\bar{L}_{O}=\frac{S_{\square}}{V}\left(\bar{J}_{A^{\prime}}+\bar{J}_{B^{\prime}}+\bar{J}_{C^{\prime}}\right) .
$$

Середні витоки через верхню і нижню основи ноди:

$$
\bar{L}_{U^{\prime}}=\frac{S_{\Delta}}{V} \bar{J}_{U^{\prime}} \quad \bar{L}_{L^{\prime}}=\frac{S_{\Delta}}{V} \bar{J}_{L^{\prime}}
$$

тут $S_{\triangle}$ - площа основи ноди, $S_{\square}$ - площа бічної грані, $V$ - об'єм ноди. Середнє значення струмів на гранях дорівнює з точністю до другого порядку малості значенням струмів у геометричних центрах відповідних граней і визначається за формулою:

$$
\bar{J}_{i^{\prime}}=\frac{2 D_{i} D_{O}}{D_{i}+D_{O}} \cdot \frac{\bar{\phi}_{O}-\bar{\phi}_{i}}{d}
$$

тут $i=A, B, C, d$ - відстань між центрами суміжних нод у радіальній площині. У разі, якщо будьяка грань призми виявиться зовнішньою (тобто, ця грань не буде спільною для жодної іншої призми), то в рівнянні (5) потрібно струм, відповідний цій грані, визначати з граничних умов, заданих на поверхні розрахункової області, наприклад, умови періодичності, відбиття або заданого альбедо (через співвідношення між парціальними струмами на цій межі).

Рівняння (5), (6) і (8) із заданими струмами $\bar{J}_{U^{\prime}}$ i $\bar{J}_{L^{\prime}}$ являють собою систему рівнянь у кінцевих різницях (finite differences) у радіальній площині. Щоб отримати замкнену систему рівнянь, необхід- но мати можливість розраховувати струми через основи призм. Цей розрахунок виконується нодальним методом. Огляд нодальних методів можна знайти в роботі [21].

Початок системи координат покладемо в центрі призми О. Орієнтація осей має бути такою, як на Рисунку 2. Після інтегрування в радіальній площині формул (1) і (2), отримуємо:

$$
\begin{gathered}
\frac{\mathrm{d} \bar{J}_{O z}}{d z}+\Sigma_{O} \bar{\phi}_{O z}=\bar{Q}_{O z}-L_{O}, \\
\bar{J}_{O z}+D_{O} \frac{d \bar{\phi}_{O z}}{d z}=0 .
\end{gathered}
$$

Тут введені позначення для поперечно зінтегрованої густини потоку і струму:

$$
\bar{\phi}_{O z} \equiv \frac{1}{S_{\Delta}} \int_{S_{\Delta}} \phi \mathrm{d} S \bar{J}_{O z} \equiv \frac{1}{S_{\triangle}} \int_{S_{\Delta}}\left(\vec{J}, \overrightarrow{e_{z}}\right) \mathrm{d} S .
$$

Відповідно до робіт [18], [20] середню поперечну густину потоку в призмі О шукаємо у вигляді розкладання в ряд за поліномами Лежандра з точністю до п'ятого доданку:

$$
\bar{\phi}_{\mathrm{Oz}}=\sum_{i=0}^{4} \bar{\phi}_{i \mathrm{O}} P_{i}(\xi)=\bar{\phi}_{\mathrm{O}}+\sum_{i=1}^{4} \bar{\phi}_{i \mathrm{O}} P_{i}(\xi)
$$

Тут координата $z=\xi h / 2$ виражена через безрозмірну змінну $\xi$. Поліноми, що використовувались у роботі [21], дозволяють зберегти неперервність середніх потоків на гранях призм, але не утворюють ортогонального набору, що ускладнює явне знаходження коефіцієнтів розкладу. Тому в цій статті використовується набір ортогональних поліномів - поліномів Лежандра. Джерела нейтронів і поперечні витоки також розкладаються в ряди, що обриваються на третьому доданку:

$$
\bar{Q}_{O z}=\sum_{i=0}^{2} \bar{Q}_{i O z} P_{i}(\xi)=\bar{Q}_{O}+\bar{Q}_{10} P_{1}(\xi)+\bar{Q}_{2 O} P_{2}(\xi) .
$$

Поперечні витоки:

$$
L_{O}=\sum_{i=0}^{2} L_{i O z} P_{i}(\xi)=\bar{L}_{O}+\bar{L}_{10} P_{1}(\xi)+\bar{L}_{20} P_{2}(\xi)
$$

Для знаходження поперечних витоків $\bar{L}_{10}$ i $\bar{L}_{20}$ використовується наближення quadratic leakage approximation, що описане в роботі [21] для іншого набору поліномів. 
Підставивши (12), (13) і (14) у рівняння (9) та (10) можна отримати систему рівнянь, що зв'язує середні струми $\bar{J}_{O z}$ і потоки $\bar{\phi}_{O z}$ на основах призми із коефіцієнтами розкладання. Ці струми та потоки можна представити через середні парціальні струми на відповідних гранях призми:

$$
\begin{array}{ll}
\bar{J}_{U^{\prime}}=\bar{J}_{O U^{\prime}}^{\text {out }}-\bar{J}_{O U^{\prime}}^{\text {in }} & \bar{\phi}_{U^{\prime}}=2\left(\bar{J}_{O U^{\prime}}^{\text {out }}+\bar{J}_{O U^{\prime}}^{\text {in }}\right), \\
\bar{J}_{L^{\prime}}=\bar{J}_{O L^{\prime}}^{\text {out }}-\bar{J}_{O L^{\prime}}^{\text {in }} & \bar{\phi}_{L^{\prime}}=2\left(\bar{J}_{O L^{\prime}}^{\text {out }}+\bar{J}_{O L^{\prime}}^{\text {in }}\right) .
\end{array}
$$

Після виконання нескладних, але довгих алгебраїчних перетворень, отримуються рівняння, що зв'язують парціальні струми на основах призми із коефіцієнтами розкладу джерел і поперечних витоків:

$$
\vec{J}_{O}^{\text {out }}=\breve{R}_{O} \vec{J}_{O}^{\text {in }}+\check{P}_{O}\left(\vec{Q}_{O}-\vec{L}_{O}\right)
$$

Отже, рівняння (16) пов'язують середні парціальні струми $\vec{J}_{O}^{\text {out }}=\left(\bar{J}_{O U^{\prime}}^{\text {out }}, \bar{J}_{O L^{\prime}}^{\text {out }}\right)^{T}$ та $\vec{J}_{O}^{\text {in }}=\left(\bar{J}_{O U^{\prime}}^{\text {in }}, \bar{J}_{O L^{\prime}}^{\text {in }}\right)^{T}$ на основах однієї призми О.

Для отримання замкнутої системи рівнянь потрібно рівняння (16) записати для кожної призми і поставити умови неперервності парціальних струмів виду $\bar{J}_{O L^{\prime}}^{\text {in }}=\bar{J}_{L^{\prime}}^{\text {out }}$ та $\bar{J}_{O U^{\prime}}^{\text {in }}=\bar{J}_{U U^{\prime}}^{\text {out }}$ д для спільних граней усіх суміжних призм, що мають вісь, яка проходить через центри основ.

У разі, якщо будь-яка з основ призми виявиться зовнішньою (тобто, ця грань не буде спільною для жодної іншої призми), то в рівнянні (16) потрібно парціальний струм, відповідний цій основі, визначати з граничних умов, заданих на поверхні всієі області.

Опишемо нарис алгоритму гібридного методу:

1) ініціалізація змінних $\bar{\phi}_{O}, \vec{j}_{O}^{\text {in }}, \vec{j}_{O}^{\text {out }}$;

2) на етапі, що передує зовнішнім ітераціям, розраховуються матриці $\breve{R}_{O}$ і $\breve{P}_{O}$ для нодального методу в кожній ноді;

3) на етапі зовнішніх ітерацій розраховуються середні і перші моменти для джерел $\bar{Q}_{0}, \bar{Q}_{10}$ та $\bar{Q}_{20}$;

4) система рівнянь (5), (6) та (7) розв'язується чисельно, і знаходяться середні значення потоків у кожній ноді $\bar{\phi}_{0}$;

5) обчислюються коефіцієнти розкладання середніх поперечних витоків $\bar{L}_{O}, \bar{L}_{10}, \bar{L}_{20}$ в кожній ноді;

6) розраховуються парціальні струми $\vec{j}_{O}^{\text {out }}$ через рівняння (16) з відомими $\bar{L}_{O}, \bar{L}_{10}, \bar{L}_{20}$ та $\bar{Q}_{O}$, $\bar{Q}_{10}, \bar{Q}_{20}$ для поперечних витоків та джерел та $\bar{j}_{0}^{\text {in }}$ на протилежних основах кожної ноди;

7) маючи розраховані значення парціальних струмів $\vec{J}_{0}^{\text {out }}$ та $\vec{j}_{0}^{\text {in }}$ обчислюються середні струми $\bar{J}_{U^{\prime}}$ і $\bar{J}_{L^{\prime}}$ на основах за формулами (15) і розраховуються $\bar{\phi}_{0}$ через рівняння (5) для відповідних нод;

8) якщо необхідна точність середніх потоків $\bar{\phi}_{0}$ досягнута, то обчислюються моменти потоків $\bar{\phi}_{10}$, $\bar{\phi}_{20}$ через відомі парціальні струми та середні потоки $\bar{\phi}_{O}$. Кроки алгоритму 4) - 7) повторюються для всіх груп нейтронів до досягнення збіжності.

Зауважимо, що $\bar{\phi}_{10}$ та $\bar{\phi}_{20}$, які розраховуються в кроці 8), не використовуються в алгоритмі гібридного методу, але необхідні для розрахунку $\bar{Q}_{10} \mathrm{i}$ $\bar{Q}_{20}$ на етапі зовнішніх ітерацій.

\section{Результати бенчмарк моделювання}

3 метою перевірки точності розрахунку ефективного коефіцієнта розмноження $\left(\mathrm{K}_{\mathrm{EFF}}\right)$ та розподілу енерговиділення $\left(\mathrm{K}_{\mathrm{v}}\right)$ під час застосування методології гібридного методу виконано моделювання бенчмарка AER-FCM101 [9]. За еталон приймається тривимірна модель активної зони реактора BBEP-1000, в якій нейтронно-фізичні параметри ТВ3 представлені попередньо заданими [9] двогруповими макроскопічними перерізами взаємодії нейтронів та коефіцієнтами дифузії. Активна зона містить ТВЗ чотирьох різних типів, які відрізняються збагаченням урану ( $\left.{ }^{235} U\right)$. Відбивачем $\epsilon$ зовнішній шар шестигранних призм, заповнених водою. чисельні значення перерізів взаємодії, а також детальний опис геометричних та матеріальних характеристик моделі наведені у [9].

Розглянуто шість випадків, які відрізняються між собою параметрами розрахункової сітки. Перші чотири випадки характеризуються розбиттям кожної шестигранної призми ТВЗ на 24 рівносторонніх трикутники (DIV), водночас в аксіальному напрямку активна зона була умовно розділена на 24, 48, 72 та 96 однакових за висотою шарів (LAY). Два останніх випадки характеризуються розбиттям ТВ3 на 54 ділянки та 24, 48 шарів за висотою. Для всіх випадків пошарові значення $\mathrm{K}_{v}$ були перераховані в 10 шарів за висотою з метою порівняння отриманих результатів з бенчмарк результатами.

Згідно з бенчмарком AER-FCM101 за референсне приймається екстрапольоване рішення методом кінцевих елементів 2-го порядку CRONOS [22]. Референсне значення ефективного коефіцієнта розмноження $\mathrm{K}_{\mathrm{EFF}}=1,049526$. Референсні значення $\mathrm{K}_{\mathrm{v}}$ для всіх типів ТВ3 наведені в Таблиці 1. Номер TВ3 відповідає номеру ТВ3 картограми в бенчмарку. Отримані гібридним та МКР методами результати ефективного коефіцієнта розмноження, а також порівняння з референсним значенням $\mathrm{K}_{\mathrm{EFF}}$ наведено в Таблиці 2.

Результати порівняння 3 референсними значеннями відносних об'ємних енерговиділень $\mathrm{K}_{\mathrm{v}}$ для випадку розбиття ТВ3 на 24 рівносторонні трикутники в радіальному напрямку та на 24 однакові за висотою шари в аксіальному напрямку наведено в Таблиці 3.

Результати порівняння з референсними значеннями відносних об'ємних енерговиділень $\mathrm{K}_{\mathrm{v}}$ 
для випадку розбиття ТВ3 на 24 рівносторонні трикутники в радіальному напрямку та на 48 однакових за висотою шарів в аксіальному напрямку наведено в Таблиці 4.

Результати порівняння 3 референсними значеннями відносних об'ємних енерговиділень $\mathrm{K}_{\mathrm{v}}$ для випадку розбиття ТВ3 на 24 рівносторонні трикутники в радіальному напрямку та на 72 однакові за висотою шари в аксіальному напрямку наведено в Таблиці 5.

Результати порівняння з референсними значеннями відносних об'ємних енерговиділень $\mathrm{K}_{\mathrm{v}}$ для випадку розбиття ТВ3 на 24 рівносторонні трикутники в радіальному напрямку та на 96 однако- вих за висотою шарів в аксіальному напрямку наведено в Таблиці 6.

Результати порівняння з референсними значеннями відносних об'ємних енерговиділень $\mathrm{K}_{v}$ для випадку розбиття ТВ3 на 54 рівносторонні трикутники в радіальному напрямку та на 24 однакові за висотою шари в аксіальному напрямку наведено в Таблиці 7.

Результати порівняння 3 референсними значеннями відносних об'ємних енерговиділень $\mathrm{K}_{\mathrm{v}}$ для випадку розбиття ТВ3 на 54 рівносторонні трикутники в радіальному напрямку та на 48 однакові за висотою шари в аксіальному напрямку, наведено в Таблиці 8.

Таблиця 1 - Референсні значення $\mathrm{K}_{\mathrm{v}}$

\begin{tabular}{|c|c|c|c|c|c|c|c|c|c|c|c|}
\hline \multirow{2}{*}{ № TВ3 } & \multicolumn{10}{|c|}{ Номер шару за висотою } & \multirow{2}{*}{ Середнє } \\
\cline { 2 - 12 } & 1 & 2 & 3 & 4 & 5 & 6 & 7 & 8 & 9 & 10 & \\
\hline 01 & 0,854 & 1,841 & 2,299 & 1,805 & 1,485 & 1,108 & 0,755 & 0,501 & 0,385 & 0,167 & 1,1199 \\
\hline 02 & 0,627 & 1,358 & 1,746 & 1,693 & 1,426 & 1,052 & 0,709 & 0,459 & 0,285 & 0,119 & 0,9475 \\
\hline 03 & 0,641 & 1,397 & 1,846 & 1,903 & 1,613 & 1,141 & 0,743 & 0,47 & 0,274 & 0,11 & 1,0138 \\
\hline 04 & 0,623 & 1,355 & 1,781 & 1,821 & 1,546 & 1,112 & 0,732 & 0,466 & 0,274 & 0,111 & 0,9821 \\
\hline 05 & 0,843 & 1,845 & 2,466 & 2,581 & 2,159 & 1,382 & 0,863 & 0,541 & 0,31 & 0,124 & 1,3112 \\
\hline 06 & 0,673 & 1,471 & 1,961 & 2,045 & 1,72 & 1,148 & 0,728 & 0,457 & 0,263 & 0,105 & 1,0571 \\
\hline 07 & 0,663 & 1,456 & 1,957 & 2,066 & 1,751 & 1,146 & 0,732 & 0,462 & 0,265 & 0,105 & 1,0603 \\
\hline 08 & 0,675 & 1,48 & 1,985 & 2,089 & 1,739 & 0,916 & 0,566 & 0,356 & 0,204 & 0,081 & 1,0091 \\
\hline 09 & 0,836 & 1,831 & 2,455 & 2,581 & 2,168 & 1,396 & 0,877 & 0,551 & 0,315 & 0,125 & 1,3135 \\
\hline 10 & 0,732 & 1,608 & 2,169 & 2,307 & 2,023 & 1,49 & 1,006 & 0,644 & 0,37 & 0,147 & 1,2495 \\
\hline 11 & 0,63 & 1,385 & 1,866 & 1,98 & 1,712 & 1,201 & 0,795 & 0,507 & 0,291 & 0,115 & 1,0481 \\
\hline 12 & 0,632 & 1,389 & 1,87 & 1,981 & 1,703 & 1,178 & 0,772 & 0,491 & 0,281 & 0,112 & 1,0409 \\
\hline 13 & 0,399 & 0,878 & 1,185 & 1,265 & 1,124 & 0,856 & 0,59 & 0,38 & 0,218 & 0,087 & 0,6981 \\
\hline 14 & 0,602 & 1,321 & 1,783 & 1,902 & 1,685 & 1,273 & 0,873 & 0,562 & 0,323 & 0,128 & 1,0452 \\
\hline 15 & 0,665 & 1,46 & 1,971 & 2,101 & 1,857 & 1,394 & 0,954 & 0,613 & 0,352 & 0,14 & 1,1508 \\
\hline 16 & 0,545 & 1,199 & 1,617 & 1,724 & 1,523 & 1,142 & 0,78 & 0,502 & 0,288 & 0,114 & 0,9434 \\
\hline 19 & 0,349 & 0,767 & 1,037 & 1,109 & 0,991 & 0,762 & 0,529 & 0,342 & 0,197 & 0,078 & 0,6161 \\
\hline 20 & 0,432 & 0,95 & 1,283 & 1,372 & 1,227 & 0,944 & 0,657 & 0,425 & 0,244 & 0,097 & 0,7631 \\
\hline
\end{tabular}

Таблиця 2 - Відхилення розрахованих гібридним та МКР методами значень $\mathrm{K}_{\mathrm{EF}}$ від референсних

\begin{tabular}{|c|c|c|c|c|c|c|c|}
\hline \multirow{3}{*}{ № } & \multicolumn{2}{|c|}{$\begin{array}{c}\text { Параметри } \\
\text { сітки }\end{array}$} & \multicolumn{5}{|c|}{ Ефективний коефіцієнт розмноження $\left(\mathrm{K}_{\mathrm{EFF}}\right)$} \\
\hline & \multirow{2}{*}{ DIV } & \multirow{2}{*}{ LAY } & \multirow{2}{*}{$\begin{array}{l}\text { Референсне } \\
\text { значення }\end{array}$} & \multicolumn{2}{|c|}{$\begin{array}{c}\text { Розрахунок гібридним } \\
\text { методом }\end{array}$} & \multicolumn{2}{|c|}{ Розрахунок МКР } \\
\hline & & & & Значення & $\begin{array}{l}\text { Відхилення, } \\
{[\mathrm{pcm}]}\end{array}$ & Значення & $\begin{array}{l}\text { Відхилення, } \\
{[\text { pсm] }}\end{array}$ \\
\hline 1 & 24 & 24 & \multirow{6}{*}{1,049526} & 1,049791 & 26,5 & 1,050355 & 82,9 \\
\hline 2 & 24 & 48 & & 1,049787 & 26,1 & 1,049958 & 43,2 \\
\hline 3 & 24 & 72 & & 1,049789 & 26,3 & 1,049864 & 33,8 \\
\hline 4 & 24 & 96 & & 1,049790 & 26,4 & 1,049830 & 30,4 \\
\hline 5 & 54 & 24 & & 1,049552 & 2,6 & 1,050120 & 59,4 \\
\hline 6 & 54 & 48 & & 1,049549 & 2,3 & 1,049720 & 19,4 \\
\hline
\end{tabular}


Аксьонов А. В., Трофименко О. Р., Будік Д. В., Носовський А. В., Гулік В. І.

Таблиця 3 - Відносні відхилення [\%] розрахованих гібридним методом $\mathrm{K}_{\mathrm{v}}$ $(\mathrm{DIV}=24, \mathrm{LAY}=24)$ від референсних

\begin{tabular}{|c|c|c|c|c|c|c|c|c|c|c|c|}
\hline \multirow{2}{*}{ № TB3 } & \multicolumn{10}{|c|}{ Hомер шару } & \multirow{2}{*}{ Середнє } \\
\cline { 2 - 11 } & 1 & 2 & 3 & 4 & 5 & 6 & 7 & 8 & 9 & 10 & \\
\hline 01 & $-3,00$ & $-2,86$ & $-2,88$ & $-3,62$ & $-3,50$ & $-3,22$ & $-2,86$ & $-2,23$ & $-1,41$ & $-0,81$ & $-2,64$ \\
\hline 02 & $-2,10$ & $-1,93$ & $-1,88$ & $-1,59$ & $-1,38$ & $-1,00$ & $-0,63$ & $-0,10$ & 0,07 & 0,04 & $-1,05$ \\
\hline 03 & $-1,95$ & $-1,78$ & $-1,66$ & $-1,44$ & $-1,22$ & $-0,81$ & $-0,24$ & 0,14 & 0,15 & 0,82 & $-0,80$ \\
\hline 04 & $-2,20$ & $-1,96$ & $-1,85$ & $-1,70$ & $-1,49$ & $-1,07$ & $-0,51$ & $-0,27$ & 0,09 & 0,18 & $-1,08$ \\
\hline 05 & $-2,12$ & $-2,00$ & $-1,91$ & $-1,72$ & $-1,54$ & $-0,60$ & 0,13 & 0,55 & 0,95 & 0,36 & $-0,79$ \\
\hline 06 & $-1,56$ & $-1,42$ & $-1,32$ & $-1,14$ & $-0,92$ & $-0,20$ & 0,36 & 0,80 & 1,08 & 1,29 & $-0,30$ \\
\hline 07 & $-0,83$ & $-0,79$ & $-0,71$ & $-0,52$ & $-0,27$ & 0,80 & 1,45 & 2,14 & 2,21 & 2,86 & 0,63 \\
\hline 08 & $-1,21$ & $-1,05$ & $-0,93$ & $-0,80$ & $-0,66$ & $-1,23$ & $-0,65$ & $-0,21$ & 0,15 & 0,62 & $-0,60$ \\
\hline 09 & $-1,97$ & $-1,79$ & $-1,72$ & $-1,58$ & $-1,30$ & $-0,33$ & 0,38 & 0,81 & 1,24 & 1,68 & $-0,46$ \\
\hline 10 & $-0,19$ & $-0,07$ & 0,00 & 0,19 & 0,49 & 1,15 & 1,78 & 2,34 & 2,63 & 2,86 & 1,12 \\
\hline 11 & $-0,34$ & $-0,23$ & $-0,13$ & 0,05 & 0,38 & 1,23 & 1,93 & 2,46 & 2,80 & 3,39 & 1,15 \\
\hline 12 & $-0,67$ & $-0,61$ & $-0,52$ & $-0,35$ & $-0,06$ & 0,78 & 1,40 & 1,89 & 2,46 & 2,28 & 0,66 \\
\hline 13 & 0,73 & 0,62 & 0,78 & 0,93 & 1,30 & 1,75 & 2,33 & 2,88 & 3,51 & 3,40 & 1,82 \\
\hline 14 & 0,04 & 0,28 & 0,36 & 0,54 & 0,87 & 1,39 & 2,06 & 2,56 & 2,99 & 3,36 & 1,45 \\
\hline 15 & $-0,12$ & 0,08 & 0,13 & 0,35 & 0,69 & 1,28 & 1,83 & 2,50 & 3,01 & 2,86 & 1,26 \\
\hline 16 & 0,27 & 0,36 & 0,51 & 0,68 & 0,97 & 1,58 & 2,22 & 2,68 & 3,19 & 3,46 & 1,59 \\
\hline 19 & 0,92 & 0,87 & 0,90 & 1,12 & 1,44 & 1,96 & 2,67 & 3,11 & 3,50 & 3,91 & 2,04 \\
\hline 20 & 0,36 & 0,44 & 0,62 & 0,82 & 1,09 & 1,66 & 2,15 & 2,79 & 3,36 & 3,03 & 1,63 \\
\hline
\end{tabular}

Таблиця 4 - Відносні відхилення [\%] розрахованих гібридним методом $\mathrm{K}_{\mathrm{v}}(\mathrm{DIV}=24, \mathrm{LAY}=48)$ від референсних

\begin{tabular}{|c|c|c|c|c|c|c|c|c|c|c|c|}
\hline \multirow{2}{*}{ № TB3 } & \multicolumn{10}{|c|}{ Hомер шару } & \multirow{2}{*}{ Середнє } \\
\cline { 2 - 12 } & 1 & 2 & 3 & 4 & 5 & 6 & 7 & 8 & 9 & 10 & \\
\hline 01 & $-2,94$ & $-2,85$ & $-2,89$ & $-3,65$ & $-3,52$ & $-3,20$ & $-2,83$ & $-2,23$ & $-1,36$ & $-0,63$ & $-2,64$ \\
\hline 02 & $-2,12$ & $-2,00$ & $-1,94$ & $-1,66$ & $-1,42$ & $-1,02$ & $-0,63$ & $-0,12$ & 0,07 & 0,13 & $-1,05$ \\
\hline 03 & $-2,01$ & $-1,90$ & $-1,77$ & $-1,54$ & $-1,28$ & $-0,87$ & $-0,29$ & 0,07 & 0,07 & 0,73 & $-0,80$ \\
\hline 04 & $-2,25$ & $-2,05$ & $-1,94$ & $-1,78$ & $-1,53$ & $-1,12$ & $-0,53$ & $-0,31$ & 0,05 & 0,18 & $-1,08$ \\
\hline 05 & $-2,22$ & $-2,17$ & $-2,05$ & $-1,84$ & $-1,61$ & $-0,68$ & 0,01 & 0,43 & 0,82 & 0,28 & $-0,79$ \\
\hline 06 & $-1,65$ & $-1,57$ & $-1,45$ & $-1,25$ & $-0,97$ & $-0,28$ & 0,27 & 0,69 & 1,01 & 1,19 & $-0,30$ \\
\hline 07 & $-0,98$ & $-0,99$ & $-0,88$ & $-0,67$ & $-0,37$ & 0,68 & 1,31 & 1,99 & 2,05 & 2,67 & 0,63 \\
\hline 08 & $-1,35$ & $-1,23$ & $-1,09$ & $-0,92$ & $-0,74$ & $-1,35$ & $-0,81$ & $-0,32$ & 0,00 & 0,49 & $-0,60$ \\
\hline 09 & $-2,06$ & $-1,95$ & $-1,86$ & $-1,69$ & $-1,36$ & $-0,41$ & 0,28 & 0,70 & 1,14 & 1,60 & $-0,46$ \\
\hline 10 & $-0,36$ & $-0,30$ & $-0,20$ & 0,02 & 0,36 & 1,02 & 1,68 & 2,21 & 2,47 & 2,72 & 1,12 \\
\hline 11 & $-0,52$ & $-0,44$ & $-0,31$ & $-0,11$ & 0,27 & 1,10 & 1,81 & 2,32 & 2,63 & 3,22 & 1,15 \\
\hline 12 & $-0,82$ & $-0,80$ & $-0,70$ & $-0,49$ & $-0,16$ & 0,67 & 1,28 & 1,79 & 2,31 & 2,19 & 0,66 \\
\hline 13 & 0,55 & 0,38 & 0,57 & 0,75 & 1,15 & 1,62 & 2,23 & 2,75 & 3,33 & 3,29 & 1,82 \\
\hline 14 & $-0,14$ & 0,05 & 0,16 & 0,36 & 0,73 & 1,28 & 1,95 & 2,42 & 2,80 & 3,21 & 1,45 \\
\hline 15 & $-0,27$ & $-0,14$ & $-0,06$ & 0,19 & 0,56 & 1,16 & 1,74 & 2,37 & 2,84 & 2,71 & 1,26 \\
\hline 16 & 0,10 & 0,16 & 0,34 & 0,53 & 0,86 & 1,48 & 2,13 & 2,58 & 3,05 & 3,29 & 1,59 \\
\hline 19 & 0,72 & 0,64 & 0,69 & 0,94 & 1,30 & 1,84 & 2,57 & 2,99 & 3,35 & 3,78 & 2,04 \\
\hline 20 & 0,20 & 0,22 & 0,42 & 0,65 & 0,95 & 1,55 & 2,06 & 2,67 & 3,20 & 2,93 & 1,63 \\
\hline
\end{tabular}


Таблиця 5 - Відносні відхилення [\%] розрахованих гібридним методом $\mathrm{K}_{\mathrm{v}}(\mathrm{DIV}=24, \mathrm{LAY}=72)$ від референсних

\begin{tabular}{|c|c|c|c|c|c|c|c|c|c|c|c|c|}
\hline \multirow{2}{*}{ № TB3 Hомер шару } & \multicolumn{10}{|c|}{ Середнє } \\
\cline { 2 - 12 } & 1 & 2 & 3 & 4 & 5 & 6 & 7 & 8 & 9 & 10 & \\
\hline 01 & $-2,90$ & $-2,84$ & $-2,86$ & $-3,67$ & $-3,53$ & $-3,20$ & $-2,85$ & $-2,25$ & $-1,34$ & $-0,57$ & $-2,60$ \\
\hline 02 & $-2,41$ & $-2,30$ & $-2,27$ & $-2,03$ & $-1,80$ & $-1,39$ & $-0,99$ & $-0,47$ & $-0,25$ & $-0,13$ & $-1,40$ \\
\hline 03 & $-2,64$ & $-2,53$ & $-2,43$ & $-2,23$ & $-1,97$ & $-1,56$ & $-0,96$ & $-0,61$ & $-0,58$ & 0,09 & $-1,54$ \\
\hline 04 & $-2,71$ & $-2,54$ & $-2,44$ & $-2,31$ & $-2,07$ & $-1,65$ & $-1,06$ & $-0,83$ & $-0,46$ & $-0,27$ & $-1,63$ \\
\hline 05 & $-3,05$ & $-3,02$ & $-2,93$ & $-2,74$ & $-2,51$ & $-1,61$ & $-0,93$ & $-0,51$ & $-0,11$ & $-0,68$ & $-1,81$ \\
\hline 06 & $-2,39$ & $-2,32$ & $-2,23$ & $-2,05$ & $-1,78$ & $-1,08$ & $-0,54$ & $-0,12$ & 0,17 & 0,43 & $-1,19$ \\
\hline 07 & $-1,98$ & $-2,01$ & $-1,93$ & $-1,74$ & $-1,44$ & $-0,46$ & 0,14 & 0,80 & 0,85 & 1,53 & $-0,62$ \\
\hline 08 & $-2,27$ & $-2,17$ & $-2,05$ & $-1,90$ & $-1,71$ & $-2,37$ & $-1,85$ & $-1,39$ & $-1,08$ & $-0,62$ & $-1,74$ \\
\hline 09 & $-2,86$ & $-2,77$ & $-2,70$ & $-2,55$ & $-2,23$ & $-1,31$ & $-0,64$ & $-0,24$ & 0,19 & 0,64 & $-1,45$ \\
\hline 10 & $-1,48$ & $-1,44$ & $-1,36$ & $-1,17$ & $-0,85$ & $-0,23$ & 0,38 & 0,88 & 1,12 & 1,36 & $-0,28$ \\
\hline 11 & $-1,58$ & $-1,54$ & $-1,42$ & $-1,24$ & $-0,89$ & $-0,10$ & 0,56 & 1,04 & 1,36 & 1,91 & $-0,19$ \\
\hline 12 & $-1,80$ & $-1,80$ & $-1,71$ & $-1,52$ & $-1,21$ & $-0,43$ & 0,16 & 0,61 & 1,14 & 1,03 & $-0,55$ \\
\hline 13 & $-0,65$ & $-0,81$ & $-0,65$ & $-0,48$ & $-0,11$ & 0,33 & 0,89 & 1,36 & 1,95 & 1,79 & 0,36 \\
\hline 14 & $-1,29$ & $-1,12$ & $-1,03$ & $-0,85$ & $-0,50$ & 0,00 & 0,64 & 1,09 & 1,44 & 1,80 & 0,02 \\
\hline 15 & $-1,37$ & $-1,25$ & $-1,20$ & $-0,97$ & $-0,62$ & $-0,05$ & 0,48 & 1,08 & 1,53 & 1,43 & $-0,09$ \\
\hline 16 & $-0,91$ & $-0,86$ & $-0,71$ & $-0,53$ & $-0,23$ & 0,36 & 0,97 & 1,38 & 1,84 & 2,06 & 0,34 \\
\hline 19 & $-0,43$ & $-0,53$ & $-0,50$ & $-0,28$ & 0,06 & 0,56 & 1,25 & 1,65 & 1,98 & 2,37 & 0,61 \\
\hline 20 & $-0,91$ & $-0,88$ & $-0,71$ & $-0,50$ & $-0,21$ & 0,34 & 0,83 & 1,40 & 1,88 & 1,59 & 0,28 \\
\hline
\end{tabular}

Таблиця 6 - Відносні відхилення [\%] розрахованих гібридним методом $\mathrm{K}_{\mathrm{v}}(\mathrm{DIV}=24, \mathrm{LAY}=96)$ від референсних

\begin{tabular}{|c|c|c|c|c|c|c|c|c|c|c|c|}
\hline \multirow{2}{*}{ № TB3 Hомер шару } & \multicolumn{1}{|c|}{ Середнє } \\
\cline { 2 - 12 } & 1 & 2 & 3 & 4 & 5 & 6 & 7 & 8 & 9 & 10 & \\
\hline 01 & $-2,89$ & $-2,83$ & $-2,86$ & $-3,68$ & $-3,53$ & $-3,21$ & $-2,85$ & $-2,25$ & $-1,31$ & $-0,57$ & $-2,60$ \\
\hline 02 & $-1,91$ & $-1,83$ & $-1,77$ & $-1,49$ & $-1,25$ & $-0,85$ & $-0,47$ & 0,03 & 0,25 & 0,29 & $-0,90$ \\
\hline 03 & $-1,67$ & $-1,58$ & $-1,45$ & $-1,22$ & $-0,95$ & $-0,56$ & 0,02 & 0,37 & 0,40 & 1,09 & $-0,56$ \\
\hline 04 & $-1,97$ & $-1,81$ & $-1,70$ & $-1,54$ & $-1,28$ & $-0,86$ & $-0,29$ & $-0,08$ & 0,31 & 0,45 & $-0,88$ \\
\hline 05 & $-1,77$ & $-1,74$ & $-1,63$ & $-1,42$ & $-1,17$ & $-0,26$ & 0,44 & 0,86 & 1,28 & 0,76 & $-0,46$ \\
\hline 06 & $-1,25$ & $-1,19$ & $-1,08$ & $-0,88$ & $-0,58$ & 0,09 & 0,65 & 1,08 & 1,39 & 1,57 & $-0,02$ \\
\hline 07 & $-0,44$ & $-0,48$ & $-0,38$ & $-0,16$ & 0,16 & 1,20 & 1,86 & 2,55 & 2,66 & 3,34 & 1,03 \\
\hline 08 & $-0,86$ & $-0,76$ & $-0,63$ & $-0,45$ & $-0,24$ & $-0,90$ & $-0,34$ & 0,15 & 0,49 & 0,99 & $-0,25$ \\
\hline 09 & $-1,63$ & $-1,54$ & $-1,46$ & $-1,29$ & $-0,94$ & 0,01 & 0,70 & 1,13 & 1,59 & 2,08 & $-0,13$ \\
\hline 10 & 0,23 & 0,27 & 0,35 & 0,57 & 0,93 & 1,61 & 2,28 & 2,83 & 3,12 & 3,34 & 1,55 \\
\hline 11 & 0,06 & 0,09 & 0,22 & 0,42 & 0,82 & 1,67 & 2,40 & 2,93 & 3,28 & 3,92 & 1,58 \\
\hline 12 & $-0,31$ & $-0,31$ & $-0,21$ & 0,00 & 0,34 & 1,18 & 1,81 & 2,32 & 2,88 & 2,82 & 1,05 \\
\hline 13 & 1,13 & 0,97 & 1,14 & 1,33 & 1,75 & 2,24 & 2,86 & 3,38 & 4,01 & 3,98 & 2,28 \\
\hline 14 & 0,46 & 0,62 & 0,73 & 0,93 & 1,31 & 1,88 & 2,57 & 3,06 & 3,48 & 3,91 & 1,90 \\
\hline 15 & 0,30 & 0,41 & 0,48 & 0,73 & 1,12 & 1,74 & 2,34 & 2,99 & 3,47 & 3,35 & 1,69 \\
\hline 16 & 0,63 & 0,66 & 0,83 & 1,03 & 1,36 & 2,00 & 2,68 & 3,14 & 3,64 & 3,90 & 1,99 \\
\hline 19 & 1,32 & 1,21 & 1,25 & 1,51 & 1,87 & 2,43 & 3,19 & 3,64 & 4,01 & 4,42 & 2,49 \\
\hline 20 & 0,75 & 0,77 & 0,95 & 1,18 & 1,51 & 2,12 & 2,66 & 3,28 & 3,81 & 3,54 & 2,06 \\
\hline
\end{tabular}


Аксьонов А. В., Трофименко О. Р., Будік Д. В., Носовський А. В., Гулік В. І.

Таблиця 7 - Відносні відхилення [\%] розрахованих гібридним методом $\mathrm{K}_{\mathrm{v}}(\mathrm{DIV}=54, \mathrm{LAY}=24)$ від референсних

\begin{tabular}{|c|c|c|c|c|c|c|c|c|c|c|c|}
\hline \multirow{2}{*}{ № TB3 } & \multicolumn{10}{|c|}{ Hомер шару } & \multirow{2}{*}{ Середн $\epsilon$} \\
\cline { 2 - 11 } & 1 & 2 & 3 & 4 & 5 & 6 & 7 & 8 & 9 & 10 & \\
\hline 01 & $-1,22$ & $-1,11$ & $-1,14$ & $-1,52$ & $-1,51$ & $-1,44$ & $-1,35$ & $-1,03$ & $-0,90$ & $-0,51$ & $-1,17$ \\
\hline 02 & $-0,59$ & $-0,45$ & $-0,47$ & $-0,35$ & $-0,32$ & $-0,17$ & $-0,08$ & 0,16 & 0,18 & 0,04 & $-0,21$ \\
\hline 03 & $-0,59$ & $-0,46$ & $-0,42$ & $-0,32$ & $-0,29$ & $-0,16$ & 0,09 & 0,16 & $-0,07$ & 0,45 & $-0,16$ \\
\hline 04 & $-0,72$ & $-0,51$ & $-0,49$ & $-0,47$ & $-0,43$ & $-0,28$ & $-0,02$ & $-0,10$ & 0,05 & 0,00 & $-0,30$ \\
\hline 05 & $-0,84$ & $-0,76$ & $-0,75$ & $-0,69$ & $-0,70$ & $-0,26$ & 0,06 & 0,12 & 0,27 & $-0,44$ & $-0,40$ \\
\hline 06 & $-0,40$ & $-0,30$ & $-0,28$ & $-0,22$ & $-0,19$ & 0,13 & 0,30 & 0,40 & 0,48 & 0,52 & 0,04 \\
\hline 07 & $-0,12$ & $-0,12$ & $-0,12$ & $-0,08$ & $-0,06$ & 0,42 & 0,60 & 0,89 & 0,66 & 1,15 & 0,32 \\
\hline 08 & $-0,34$ & $-0,21$ & $-0,17$ & $-0,17$ & $-0,21$ & $-0,57$ & $-0,37$ & $-0,29$ & $-0,25$ & 0,00 & $-0,26$ \\
\hline 09 & $-0,82$ & $-0,67$ & $-0,69$ & $-0,67$ & $-0,61$ & $-0,17$ & 0,10 & 0,15 & 0,32 & 0,56 & $-0,25$ \\
\hline 10 & $-0,07$ & 0,01 & 0,00 & 0,04 & 0,08 & 0,31 & 0,47 & 0,63 & 0,61 & 0,61 & 0,27 \\
\hline 11 & 0,01 & 0,07 & 0,09 & 0,13 & 0,20 & 0,54 & 0,75 & 0,88 & 0,91 & 1,31 & 0,49 \\
\hline 12 & $-0,09$ & $-0,06$ & $-0,06$ & $-0,02$ & 0,02 & 0,35 & 0,51 & 0,61 & 0,89 & 0,58 & 0,27 \\
\hline 13 & 0,10 & $-0,04$ & 0,03 & 0,04 & 0,15 & 0,20 & 0,33 & 0,46 & 0,80 & 0,52 & 0,26 \\
\hline 14 & $-0,21$ & 0,00 & 0,01 & 0,03 & 0,11 & 0,23 & 0,43 & 0,52 & 0,63 & 0,86 & 0,26 \\
\hline 15 & $-0,11$ & 0,05 & 0,02 & 0,09 & 0,18 & 0,36 & 0,46 & 0,71 & 0,91 & 0,57 & 0,32 \\
\hline 16 & 0,25 & 0,30 & 0,37 & 0,39 & 0,42 & 0,63 & 0,81 & 0,87 & 1,08 & 1,18 & 0,63 \\
\hline 19 & 0,14 & 0,07 & 0,00 & 0,08 & 0,15 & 0,28 & 0,55 & 0,57 & 0,71 & 0,96 & 0,35 \\
\hline 20 & $-0,15$ & $-0,09$ & $-0,02$ & 0,05 & 0,07 & 0,25 & 0,31 & 0,53 & 0,78 & 0,36 & 0,21 \\
\hline
\end{tabular}

Таблиця 8 - Відносні відхилення [\%] розрахованих гібридним методом $\mathrm{K}_{\mathrm{v}}(\mathrm{DIV}=54, \mathrm{LAY}=48)$ від референснихреференсних

\begin{tabular}{|c|c|c|c|c|c|c|c|c|c|c|c|}
\hline \multirow{2}{*}{$№$ TB3 } & \multicolumn{10}{|c|}{ Hомер шару } & \multirow{2}{*}{ Середнє } \\
\cline { 2 - 11 } & 1 & 2 & 3 & 4 & 5 & 6 & 7 & 8 & 9 & 10 & \\
\hline 01 & $-1,16$ & $-1,10$ & $-1,15$ & $-1,55$ & $-1,53$ & $-1,43$ & $-1,32$ & $-1,03$ & $-0,84$ & $-0,27$ & $-1,14$ \\
\hline 02 & $-0,57$ & $-0,48$ & $-0,49$ & $-0,38$ & $-0,31$ & $-0,15$ & $-0,04$ & 0,19 & 0,21 & 0,21 & $-0,18$ \\
\hline 03 & $-0,59$ & $-0,51$ & $-0,45$ & $-0,35$ & $-0,27$ & $-0,14$ & 0,11 & 0,16 & $-0,07$ & 0,54 & $-0,16$ \\
\hline 04 & $-0,71$ & $-0,56$ & $-0,52$ & $-0,48$ & $-0,41$ & $-0,25$ & 0,01 & $-0,08$ & 0,09 & 0,09 & $-0,28$ \\
\hline 05 & $-0,84$ & $-0,83$ & $-0,79$ & $-0,70$ & $-0,67$ & $-0,24$ & 0,05 & 0,12 & 0,27 & $-0,44$ & $-0,41$ \\
\hline 06 & $-0,40$ & $-0,36$ & $-0,32$ & $-0,24$ & $-0,16$ & 0,14 & 0,32 & 0,40 & 0,48 & 0,52 & 0,04 \\
\hline 07 & $-0,15$ & $-0,21$ & $-0,17$ & $-0,10$ & $-0,03$ & 0,43 & 0,59 & 0,89 & 0,66 & 1,15 & 0,31 \\
\hline 08 & $-0,36$ & $-0,28$ & $-0,22$ & $-0,18$ & $-0,16$ & $-0,57$ & $-0,41$ & $-0,29$ & $-0,25$ & 0,12 & $-0,26$ \\
\hline 09 & $-0,82$ & $-0,74$ & $-0,73$ & $-0,69$ & $-0,57$ & $-0,15$ & 0,10 & 0,15 & 0,32 & 0,56 & $-0,26$ \\
\hline 10 & $-0,10$ & $-0,08$ & $-0,06$ & 0,01 & 0,09 & 0,33 & 0,51 & 0,64 & 0,61 & 0,68 & 0,26 \\
\hline 11 & $-0,04$ & $-0,01$ & 0,03 & 0,10 & 0,22 & 0,55 & 0,77 & 0,88 & 0,91 & 1,31 & 0,47 \\
\hline 12 & $-0,12$ & $-0,14$ & $-0,11$ & $-0,05$ & 0,04 & 0,37 & 0,53 & 0,63 & 0,89 & 0,58 & 0,26 \\
\hline 13 & 0,05 & $-0,14$ & $-0,04$ & 0,00 & 0,15 & 0,22 & 0,38 & 0,49 & 0,76 & 0,52 & 0,24 \\
\hline 14 & $-0,24$ & $-0,09$ & $-0,06$ & $-0,01$ & 0,11 & 0,26 & 0,48 & 0,55 & 0,63 & 0,86 & 0,25 \\
\hline 15 & $-0,14$ & $-0,04$ & $-0,05$ & 0,06 & 0,18 & 0,38 & 0,50 & 0,74 & 0,91 & 0,64 & 0,32 \\
\hline 16 & 0,21 & 0,22 & 0,32 & 0,36 & 0,44 & 0,66 & 0,86 & 0,91 & 1,08 & 1,18 & 0,62 \\
\hline 19 & 0,09 & $-0,03$ & $-0,06$ & 0,04 & 0,14 & 0,30 & 0,59 & 0,63 & 0,66 & 0,96 & 0,33 \\
\hline 20 & $-0,17$ & $-0,19$ & $-0,08$ & 0,00 & 0,06 & 0,28 & 0,36 & 0,58 & 0,78 & 0,36 & 0,20 \\
\hline
\end{tabular}


у Таблиці 9 наведені значення максимальних відносних відхилень $\mathrm{K}_{\mathrm{v}}$ та відповідні середньоквадратичні відхилення (СКВ), отримані новим методом та методом скінченних різниць для кожного розглянутого випадку розрахункової сітки. СКВ розраховувалось для всіх шарів ТВЗ.

Для співставлення, у Таблиці 10 наведені результати порівняння з референсними значеннями відносних об'ємних енерговиділень $\mathrm{K}_{\mathrm{v}}$ отриманих методом МКР для випадку розбиття ТВЗ на 54 рівносторонні трикутники в радіальному напрямку та на 48 однакових за висотою шарів в аксіальному напрямку.

Аналізуючи отримані порівняння розрахунку гібридного методу з бенчмарком, привертає увагу той факт, що у разі значного збільшення кількості нод за висотою активної зони, точність розрахунку починає падати. Це можливо пояснити декількома чинниками:

1) Висота ноди стає меншою ніж довжина радіальної бічної грані ноди, і розрахунок бічних витоків через потоки в сусідніх нодах у радіальній площині стає менш точним.

2) Розміри нод загалом стають занадто малими i, як наслідок, погіршуються умови для застосування квадратичної апроксимації для бічних витоків (див., наприклад, вступ у статті [23]).

Аналізуючи отримані порівняння розрахунку МКР методом з бенчмарком, можна побачити, що перший та десятий шари за висотою мають досить суттєве відхилення (див. Таблицю 10) за тієї самої сітки (DIV $=54, \mathrm{LAY}=48)$ порівняно 3 гібридним методом.

Таблиця 9 - Максимальні відносні відхилення $\mathrm{K}_{\mathrm{v}}$ та CКВ для кожного розглянутого випадку розрахункової сітки

\begin{tabular}{|c|c|c|c|c|c|c|}
\hline \multirow{3}{*}{ № } & & & \multicolumn{2}{|c|}{ Гібридний метод } & \multicolumn{2}{|c|}{ MKP } \\
\hline & \multicolumn{2}{|c|}{$\begin{array}{c}\text { Параметри } \\
\text { сітки }\end{array}$} & \multirow{2}{*}{$\begin{array}{c}\text { Максимальне } \\
\text { відхилення, [\%] }\end{array}$} & \multirow{2}{*}{ CKB, [\%] } & \multirow{2}{*}{$\begin{array}{c}\text { Максимальне } \\
\text { відхилення, [\%] }\end{array}$} & \multirow{2}{*}{ CKB, [\%] } \\
\hline & DIV & LAY & & & & \\
\hline 1 & 24 & 24 & 3,908 & 1,678 & 19,85 & 7,252 \\
\hline 2 & 24 & 48 & 3,780 & 1,654 & 6,34 & 2,415 \\
\hline 3 & 24 & 72 & 3,670 & 1,395 & 4,80 & 1,701 \\
\hline 4 & 24 & 96 & 4,420 & 1,787 & 4,29 & 1,624 \\
\hline 5 & 54 & 24 & 1,520 & 0,531 & 19,42 & 7,355 \\
\hline 6 & 54 & 48 & 1,548 & 0,538 & 5,68 & 2,090 \\
\hline
\end{tabular}

Таблиця 10 - Відносні відхилення [\%] розрахованих методом MKP K $(\mathrm{DIV}=54, \mathrm{LAY}=48)$ від референсних

\begin{tabular}{|c|c|c|c|c|c|c|c|c|c|c|c|}
\hline \multirow{2}{*}{ № TB3 } & \multicolumn{10}{|c|}{ Hомер шару } & \multirow{2}{*}{ Середнє } \\
\cline { 2 - 12 } & 1 & 2 & 3 & 4 & 5 & 6 & 7 & 8 & 9 & 10 & \\
\hline 01 & 4,35 & 0,54 & $-0,29$ & $-2,37$ & $-2,37$ & $-2,66$ & $-2,83$ & $-2,81$ & $-0,84$ & 2,55 & $-0,67$ \\
\hline 02 & 5,12 & 1,15 & $-0,06$ & $-0,81$ & $-1,13$ & $-1,39$ & $-1,57$ & $-1,34$ & $-0,32$ & 3,15 & 0,28 \\
\hline 03 & 5,06 & 1,07 & $-0,16$ & $-0,72$ & $-1,03$ & $-1,40$ & $-1,41$ & $-1,33$ & $-0,77$ & 3,27 & 0,26 \\
\hline 04 & 4,94 & 1,03 & $-0,21$ & $-0,87$ & $-1,20$ & $-1,50$ & $-1,51$ & $-1,55$ & $-0,60$ & 2,97 & 0,15 \\
\hline 05 & 4,63 & 0,69 & $-0,55$ & $-1,08$ & $-1,27$ & $-1,64$ & $-1,48$ & $-1,38$ & $-0,53$ & 2,05 & $-0,06$ \\
\hline 06 & 5,19 & 1,18 & $-0,07$ & $-0,62$ & $-0,83$ & $-1,20$ & $-1,21$ & $-1,08$ & $-0,32$ & 3,19 & 0,42 \\
\hline 07 & 5,39 & 1,29 & 0,04 & $-0,50$ & $-0,66$ & $-0,98$ & $-0,96$ & $-0,63$ & $-0,17$ & 3,72 & 0,65 \\
\hline 08 & 5,20 & 1,23 & 0,00 & $-0,56$ & $-0,43$ & $-2,48$ & $-1,94$ & $-1,78$ & $-1,03$ & 2,47 & 0,07 \\
\hline 09 & 4,61 & 0,76 & $-0,51$ & $-1,08$ & $-1,18$ & $-1,56$ & $-1,44$ & $-1,35$ & $-0,51$ & 3,12 & 0,09 \\
\hline 10 & 5,25 & 1,39 & 0,12 & $-0,44$ & $-0,74$ & $-0,97$ & $-1,05$ & $-0,89$ & $-0,26$ & 3,07 & 0,55 \\
\hline 11 & 5,47 & 1,47 & 0,23 & $-0,33$ & $-0,52$ & $-0,80$ & $-0,79$ & $-0,64$ & 0,05 & 3,83 & 0,80 \\
\hline 12 & 5,40 & 1,34 & 0,08 & $-0,47$ & $-0,68$ & $-0,99$ & $-1,02$ & $-0,90$ & 0,04 & 3,09 & 0,59 \\
\hline 13 & 5,29 & 1,30 & 0,14 & $-0,47$ & $-0,73$ & $-1,07$ & $-1,18$ & $-1,04$ & $-0,11$ & 2,82 & 0,49 \\
\hline 14 & 5,02 & 1,37 & 0,11 & $-0,46$ & $-0,76$ & $-1,04$ & $-1,09$ & $-1,00$ & $-0,23$ & 3,21 & 0,51 \\
\hline 15 & 5,20 & 1,42 & 0,13 & $-0,40$ & $-0,68$ & $-0,93$ & $-1,06$ & $-0,81$ & 0,03 & 3,00 & 0,59 \\
\hline 16 & 5,68 & 1,68 & 0,49 & $-0,10$ & $-0,43$ & $-0,65$ & $-0,72$ & $-0,65$ & 0,21 & 3,64 & 0,91 \\
\hline 19 & 5,31 & 1,41 & 0,11 & $-0,44$ & $-0,76$ & $-1,01$ & $-0,98$ & $-0,92$ & $-0,20$ & 3,27 & 0,58 \\
\hline 20 & 5,05 & 1,25 & 0,09 & $-0,47$ & $-0,84$ & $-1,02$ & $-1,21$ & $-0,98$ & $-0,12$ & 2,62 & 0,44 \\
\hline
\end{tabular}




\section{Висновки}

Запропоновано використання так званого гібридного (МКР/нодальний) методу рішення системи двогрупових дифузійних рівнянь для підсистеми фізичних розрахунків (ПФР) CBPK-M2. Це дозволяє досягти оптимального співвідношення між точністю і швидкістю розрахунку для задач моніторингу в СВРК.

Наведено алгоритм рішення системи двогрупових дифузійних рівнянь гібридним методом для гексогональної геометрії. Гібридний метод був реалізований в ПФР CВPК-M2 із застосуванням мови програмування $\mathrm{C}++$.

Виконано порівняння результатів розрахунків гібридного методу з результатами бенчмарка AER-FCM101 для різного рівня розбиття активної зони на ноди в радіальному та аксіальному напрямках. Показано, що можна досягти відхилення від результатів бенчмарка приблизно 2-3 рст для ефективного коефіцієнта розмноження. Найкраще узгодження 3 бенчмарком за енерговиділенням (для $\mathrm{K}_{\mathrm{v}}$ максимальне відхилення - 1,52 \%, СКВ - 0,531 \%) досягається за 54 нодами на одну ТВ3 в плані та за 24 однаковими за висотою шарами в аксіальному напрямку.

Гібридний метод, для тієї самої розрахункової сітки, дає вищу точність ніж метод кінцевих різниць, особливо в областях 3 високою неоднорідністю розподілу нейтронів.

\section{Подяка}

Автори висловлюють вдячність Петровському Юрію Леонідовичу (відділ ядерної безпеки Запоріжської AEC) за ідею застосування описаного методу та практичну допомогу під час проведення досліджень.

\section{Список використаної літератури}

1. Core Monitoring for Commercial Reactors: Improvements in Systems and Methods. Workshop Proceedings, Stockholm, Sweden, 4-5 October 1999.

2. Калинушкин А.Е., Курченков А.Ю., Митин В.И., Семченков Ю. М. Современная система внутриреакторного контроля (СВРК-М), мониторинг ядерного топлива ВВЭР-1000. Ядерна та радіачійна безпека. 2010. № 4(48). C.18- 21 .
3. Saeed A., Rashid A. Development of Core Monitoring System for a Nuclear Power Plant using Artificial Neural Network Technique. Annals of Nuclear Energy. 2020. Vol. 144, 107513. doi: 10.1016/j.anucene.2020.107513144.

4. Fujitsuka N., Tanouchi H., Imamura Y., Mizobuchil D., Kanagawa T., Masuda M. Experience and evaluation of advanced on-line core monitoring system 'BEACON' at IKATA site, Proceedings of a Specialists' Meeting on In-Core Instrumentation and Core Assessment. Nuclear Energy Agency of the OECD (NEA).1997, P. 103-113.

5. Kovbasenko Y. Comparative Analysis of VVER-1000 Westinghouse and TVEL Spent Fuel Capability. Universal Journal of Physics and Application. 2016. Vol. 10, No. 4. P. 105 - 109. doi: 10.13189/ujpa.2016.100401.

6. Халимончук В. А. Функционирование программного обеспечения СВРК ВВЭР-1000 верхнего уровня в условиях реализации в Украине расширенной программы по диверсификации ядерного топлива. Ядерна тарадіаційна безпека. 2015. № 1(65). С. 7 - 12.

7. Протокол № 3 від 12.11.2016 р. засідання НТР ДП «НАЕК «Енергоатом» по темі: «Розробка національного розрахункового комплексу СВРК-М2», пункт 2 розділу «Постановили».

8. Разработка национального расчетного комплекса определения нейтронно-физических и тепло-гидравлических параметров реакторной установки и создание модернизированного комплекса унифицированного программного обеспечения систем внутриреакторного контроля энергоблоков ВВЭР-1000 АЭС Украины: техническое задание ИТКЯ.421412.114Т3, 2018.

9. Schulz G. Solutions of a 3D VVER-1000 Benchmark. Proc. 6-th Symposium of AER on VVER Reactor Physics and Safety, Kirkkonummi, Finland, September 1996.

10. Вейнберг А., Вигнер Е. Физическая теория ядерных реакторов. М.: Издательство иностранной литературы, 1961.724 c.

11. Павлович В.М. Фізика ядерних реакторів. К.: Інститут проблем безпеки АЕС, 2009. 224 с.

12. Белл Д., Глесстон С. Теория ядерных реакторов. М.: Атомиздат, 1974. 489 с.

13. Studsvik Scandpower. SIMULATE-3: Advanced Three-Dimensional Two-Group Reactor Analysis Code: User's Manual; Technical Report No. SSP-09/447-U; Studsvik Scandpower: Nyköping, Sweden, 2009.

14. Downar T., Xu Y., Seker V. PARCS, v3.0 U.S. NRC Core Neutronics Simulator: User Manual; Technical report No. UM-NERS-09-0001; University of Michigan: Ann Arbor, MI, USA, 2013.

15. Cho J., Song J., Lee K. Three dimensional nuclear analysis system DeCART/CHORUS/MASTER. In Proceedings of the ANS Annual Meeting, Atlanta, GA, USA, 16-20 June 2013.

16. Singh T., Mazumdar T., Pandey P., Varde P. V. Overview of Reactor Core Level Calculation by Nodal and Finite Difference Methods. SRESA's International Journal of Life Cycle Reliability and Safety Engineering. Vol. 4, No. 4, P. 11 - 21.

17. Жуков А.И. Применение метода локальных вариаций для нейтронно-физических расчётов. Вопросы атомной науки и техники. 2006. № 4(89). С.128 - 132. 
18. Lee, D. J., Choi, H., Lee, K. H., Kim, Y. H. NEM and FDM Hybrid Method for 3-Dimensional Reactor Core Analysis. Proceedings of the Korean Nuclear Society Autumn Meeting. Seoul, Korea, October 1999.

19. Stacey W. M. Nuclear Reactor Physics, Second Edition, Completely Revised and Enlarged Edition. Wiley-VCH Verlag, 2007. 735 p.

20. Lee D., Kim Y., Kim Y. A Consistent Coupling of Nodal Expansion Method, Analytic Nodal Method, and Finite Difference Method for 3-Dimensional Reactor Core Analysis. Proceedings of PHYSOR 2010: Advances in Reactor Physics to Power the Nuclear Renaissance. Pittsburg, Pennsylvania, USA, May 2010.

21. Lawrence R. D. Progress in nodal methods for the solution of the neutron diffusion and transport equations. Progress in Nuclear Energy. 1986. Vol. 17, No. 3, P. $271-301$. doi: 10.1016/0149-1970(86)90034-X.

22. Kolev N. P., Lenain R., Fedon-Magnaud C., CRONOS Solutions of the AER 3D Benchmark for VVER-1000, CEA Internal Report, Saclay, 1997.

23. Prinsloo R. H., Tomašević D. I., Moraal H. A practical implementation of the higher-order transverse-integrated nodal diffusion method. Annals of Nuclear Energy. 2014. Vol. 68, P. 70 - 88. doi: 10.1016/j.anucene.2014.01.010.

\section{References}

1. Core Monitoring for Commercial Reactors: Improvements in Systems and Methods, Workshop Proceedings, Stockholm, Sweden, 4-5 October 1999.

2. Kalinushkin, A., Kurchenkov, A., Mitin, V., Semchenkov, Y. (2010). Modern In-Core Monitoring System (ICMS-M) and Monitoring of WWER-1000 Nuclear Fuel. Nuclear and Radiation Safety, 4(48), $18-21$.

3. Saeed, A., Rashid, A. (2020). Development of Core Monitoring System for a Nuclear Power Plant using Artificial Neural Network Technique. Annals of Nuclear Energy, 144, 107513. doi: 10.1016/j.anucene.2020.107513144.

4. Fujitsuka, N., Tanouchi, H., Imamura, Y., Mizobuchil, D., Kanagawa, T., Masuda, M. (1996). Experience and Evaluation of Advanced On-Line Core Monitoring System BEACON at IKATA Site. Proceedings of a Specialists' Meeting on In-Core Instrumentation and Core Assessment. Nuclear Energy Agency of the OECD (NEA), $103-113$.

5. Kovbasenko, Y. (2016). Comparative Analysis of VVER-1000 Westinghouse and TVEL Spent Fuel Capability. Universal Journal of Physics and Application, 10 (4), 105 - 109. doi: 10.13189/ujpa.2016.100401.

6. Khalimonchuk, V. (2015). Top-Level Software for VVER-1000 In-core Monitoring System under Implementation of Expanded Nuclear Fuel Diversification Program in Ukraine. Nuclear and Radiation Safety, 1(65), 7 - 12.

7. Protocol № 3 dated 12.11.2016 for the meeting of State Enterprise «National Nuclear Energy Generating Company «Energoatom» on the topic: «Development of the national calculation complex SVRK-M2», item 2 of the section «Resolved».
8. Terms of Reference ITKYa.421412.114T3. Development of a National Computational Complex for Determining the Neutronic and Thermal-Hydraulic Parameters of a Reactor Facility and the Development of a Modernized Complex of Unified Software for In-Core Monitoring Systems for WWER-1000 Power Units of Ukrainian NPPs. 2018.

9. Schulz, G. (1996). Solutions of a 3D VVER-1000 Benchmark, Proc. 6-th Symposium of AER on VVER Reactor Physics and Safety. Kirkkonummi, Finland, September 1996.

10. Weinberg, A. M., Wigner, E.P. (1961). The Physical Theory of Neutron Chain Reactors. Moscow. Foreign Literature Publishing House, 724.

11. Pavlovych, V. (2009). Physics of Nuclear Reactors. Kyiv. Institute for Safety Problems of NPPs. 224.

12. Bell, G. I., Glasstone, S. (1974). Nuclear Reactor Theory, Moscow, Atomizdat, 489.

13. Technical Report No. SSP-09/447-U. SIMULATE-3: Advanced Three-Dimensional Two-Group Reactor Analysis Code User's Manual. Studsvik Scandpower, Nyköping, Sweden, 2009.

14. Downar, T., Xu, Y., Seker, V. (2013). PARCS, v3.0 US NRC Core Neutronics Simulator User Manual. Technical report No. UM-NERS-09-0001. University of Michigan, Ann Arbor, MI, USA.

15. Cho, J., Song, J., Lee, K. (2013). Three Dimensional Nuclear Analysis System DeCART/CHORUS/MASTER. In Proceedings of the ANS Annual Meeting, Atlanta, GA, USA, 16-20 June 2013.

16. Singh, T., Mazumdar, T., Pandey, P., et all. (2015). Overview of Reactor Core Level Calculation by Nodal and Finite Difference Methods. SRESA's International Journal of Life Cycle Reliability and Safety Engineering, 4(4), 11 - 21.

17. Zhukov, A. I. (2006). Use of Local Variation Method for Nuclear Design Calculations. Problems of Atomic Science and Technology, 4(89), 128 - 132.

18. Lee, D. J., Choi, H., Lee, K. H., Kim, Y. H. (1999). NEM and FDM Hybrid Method for 3-Dimensional Reactor Core Analysis. Proceedings of the Korean Nuclear Society Autumn Meeting. Seoul, Korea, October 1999.

19. Stacey, W. M. (2007). Nuclear Reactor Physics. Second Edition. Wiley-VCH Verlag, 735.

20. Lee, D., Kim, Y., Kim, Y. (2010). A Consistent Coupling of Nodal Expansion Method, Analytic Nodal Method, and Finite Difference Method for 3-Dimensional Reactor Core Analysis. Proceedings of PHYSOR 2010. Advances in Reactor Physics to Power the Nuclear Renaissance. Pittsburg, Pennsylvania, USA, May 2010.

21. Lawrence, R. D. (1986). Progress in Nodal Methods for the Solution of the Neutron Diffusion and Transport Equations. Progress in Nuclear Energy, 17(3), 271-301. doi: 10.1016/0149-1970(86)90034-X.

22. Kolev, N., Lenain, R., Fedon-Magnaud, C., (1997). CRONOS Solutions of the AER 3D Benchmark for VVER-1000. CEA Internal Report, Saclay.

23. Prinsloo, R. H., Tomašević, D. I., Moraal, H. (2014). A practical Implementation of the Higher-Order TransverseIntegrated Nodal Diffusion Method. Annals of Nuclear Energy, 68, 70 - 88. doi: 10.1016/j.anucene.2014.01.010. 
The New Method for Solving a System of Two Group Diffusion Equations on In-Core Monitoring System Software for WWER-1000

\section{Aksonov A. ${ }^{,}$, Trofymenko O. ', Budik D. ${ }^{1}$,} Nosovskyi A. ${ }^{2}$, Gulik V. ${ }^{1}$

\author{
${ }^{1}$ SRPA «Impulse», Severodonetsk, Lugansk \\ region, Ukraine \\ ${ }^{2}$ Institute for Safety Problems of NPP of the \\ National Academy of Sciences of Ukraine, Kyiv, \\ Ukraine
}

Accurate and up-to-date information on the operational characteristics of a nuclear reactor, the source of which is the In-Core Monitoring System, makes it possible to assess the safety level of the operating of NPP units. At present, Ukraine is completing the development of its own reactor calculation software for WWER-1000, which is one of the important conditions for implementation of the nuclear fuel diversification program. The research team of SRPA «Impulse» has developed a reactor calculation software for the national calculation complex based on a hybrid method of solving a system of two-group diffusion equations, which combines the finite differences method and the nodal method. The paper presents the methodology for solving the system of twogroup diffusion equations by the hybrid method for hexagonal geometry. A comparison of the calculation performed by the developed code based on the hybrid method with the data presented in the benchmark AER-FCM101. The results of the comparison with the benchmark indicate the high accuracy of the developed software for calculating the discrete reactor core state. This allows achieving the optimal ratio between the accuracy and speed of calculation for monitoring tasks in the In-Core Monitoring System. It is demonstrated that it is possible to achieve a deviation from the results of the benchmark of the order of $2-3 \mathrm{pcm}$ for the effective multiplication factor. The best agreement with the benchmark on energy release (for $\mathrm{K}_{\mathrm{v}}$ maximum deviation is $1.52 \%$ and standard deviation is $0.531 \%$ ) is achieved at 54 nodes per fuel assembly in the radial direction and at 24 identical in height layers in the axial direction. The hybrid method, for the same calculation grid, gives higher accuracy than the finite difference method, especially in areas with high neutron distribution inhomogeneity.

Keywords: In-Core Monitoring System, nuclear reactor calculation, software, hybrid method, benchmark AER-FCM101.

Отримано 01.02.2021 